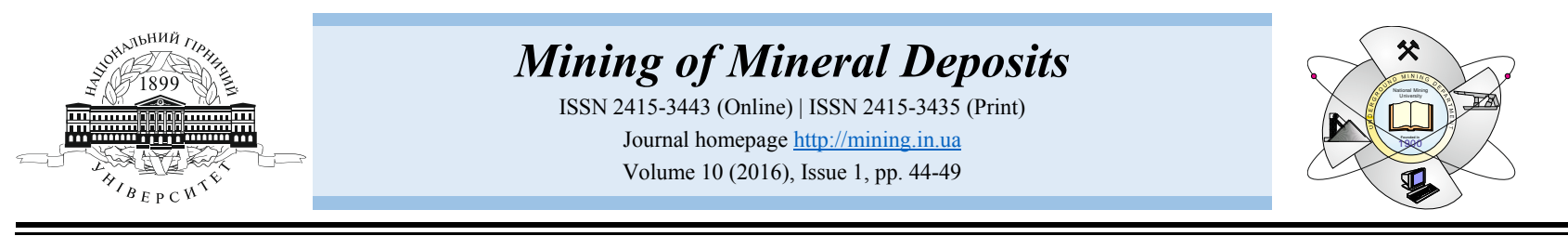

UDC 622.28

\title{
INCREASING STABILITY OF UNDERGROUND MINE WORKINGS BY FORMING NEW GEOTECHNICAL PROPERTIES OF ADJOINING LAYERS VIA ROLLER COMPACTION
}

\author{
V. Kravets ${ }^{1}$, S. Zaychenko ${ }^{2 *}$, G. Gayko ${ }^{1}$

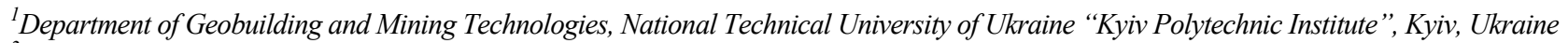 \\ ${ }^{2}$ Department of Electromechanics Equipment Productions, National Technical University of Ukraine "Kyiv Polytechnic Institute", \\ Kyiv, Ukraine \\ *Corresponding author: e-mail zstef@gmail.com, tel. +380668632729
}

\section{ПІДВИЩЕННЯ СТІЙКОСТІ ПІДЗЕМНИХ ВИРОБОК ШЛЯХОМ ФОРМУВАННЯ НОВИХ ГЕОТЕХНІЧНИХ ВЛАСТИВОСТЕЙ ПРИЛЕГЛИХ ШАРІВ МЕТОДОМ РОЛИКОВОГО УЩІЛЬНЕННЯ}

\author{
В. Кравець ${ }^{1}$, С. Зайченко ${ }^{2 *}$, Г. Гайко ${ }^{1}$ \\ ${ }^{1}$ Кафедра геобудівництва та гірничих технологій, Національний технічний університет Украйни "Київський політехнічний \\ інститут”, Київ, Україна \\ ${ }^{2}$ Кафедра електромеханічного обладнання енергоємних виробнищтв, Національний технічний університет Украӥни "Київсь- \\ кий політехнічний інститут”, Київ, Украӥна \\ *Biдповідальний автор: e-mail zstef@gmail.com, тел. +380668632729
}

\begin{abstract}
Purpose. To create a model reproducing the process of forming geotechnical properties of the rock massif adjoining circuit of underground excavation by roller compaction method incorporating hardening and creating the zone of slow plastic deformation.

Methods. Modelling the main technological parameters of manufacturing process as for adjoining circuit of the tunnel: distribution of normal pressures and heights of the core seal depending on the main strength and deformation properties of rock massif, geometry and characteristics of the contact area of roller working body with the working medium.

Findings. The choice of the computational model simulating the formation of adjoining mountain contour properties by roller method has been justified taking into account the processes caused by soil deformation: appearance of elastic and plastic deformation, change of soil characteristics, formation of compaction core. The main stages and parameters interrelations in modelling the processing of the tunnel adjoining zone are shown.

Originality. Scientific novelty is referred to the development of a method to analyze contact interaction of the roller working body of a molding machine with the massif, considering changes in the process of the treated medium physical and mechanical properties stabilization, with the aim to predict the required stress and depth of the formed layer.

Practical implications. The research allowed to infer theoretical fundamentals for the formation of geotechnical properties inherent to the adjoining contour of underground excavation by roller method, taking into account peculiarities of soil deformation and contact interaction of the working body with the environment which allows to improve the tunnel construction technology by strengthening the carrying capacity of the marginal massif. The obtained results are instrumental in determining parameters of the elastic and plastic deformations zone with the view to establishing its height and stresses.
\end{abstract}

Keywords: geotechnical properties, roller compaction, deformation, computer simulation

\section{INTRODUCTION}

Seal polydisperse system is the main process for a variety of industries. In particular, the production of building materials and construction quality of seal mixtures identifies the main technical and operational performance of a product (Hopkinson, Myatt \& Tajbakhsh, 2004).

Despite the existence of different ways of concrete mixtures sealing, the most effective are the methods of densification which makes it possible to create in a 
sealed environment a strained condition resulting from normal and shear stresses. One of the ways that implements the given principle is a method of roller compaction. This method proved itself in the construction of monolithic structures, in particular, hydraulic structures (Berga, 2003), roads (Vahedifard, Nili \& Meehan, 2010).

The current stage of tunnel construction development is characterized by using a combination of multiple mounting with monolithic and prefabricated elements (Miura, 2003; Ramoni \& Anagnostou, 2010). Roller compaction of monolithic structures can be used for creating of monolithic refinement layers (Zenunović \& Folić, 2012; (Zinchuk, Mullarney \& Hancock, 2004)). The new technology requires to study the process of sealing the tunnel by roller compaction method because of stresses occurring in the environment, which are linked by the way of interacting with roller working body.

The most approximate theoretical and experimental research into the process of roller compaction is described in the works devoted to the interaction of the wheel with the ground (Hambleton \& Drescher, 2008; Chiroux, Foster, Johanson, Shoop \& Raper, 2005; Hambleton \& Drescher, 2008).

In these studies, the process is modeled by a rigid cylinder interacting with a semispace under the known value of power agitation or quantity of rainfall, where the material properties are represented by constant coefficients of models (Mohr-Coulomb, Drucker-Prager, Jung).

\section{SIMULATION METHODOLOGY}

During processing of adjoining layers by a roller, for the case of circular outline of tunnel construction, upon the completion of the process of adjacent circuit geotechnical properties formation, soil rock massive will be divided into layers in the form of concentric circles (Fig. 1).

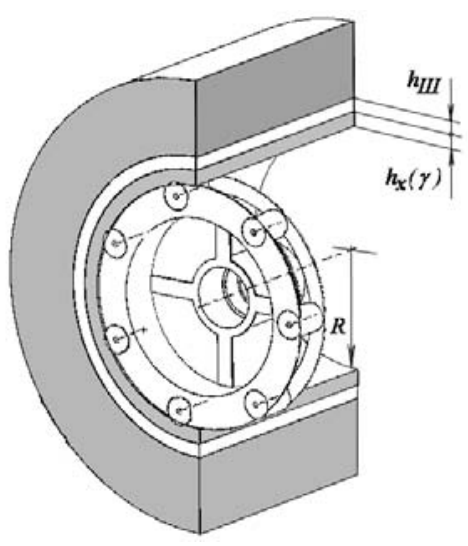

Figure 1. Zones of roller bodies force impact on soil massive

\section{RESULTS AND DISCUSSION}

Sizes (radiuses) of adjacent contour layers of soil massive, in which there are various types of deformations:

- slow deformation zone:

$z \in\left(R_{m} ; R_{m}+h_{x}(\gamma)\right) ;$

- developed plastic deformation zone: $z \in\left(R_{m}+h_{x}(\gamma) ; R_{m}+h_{x}(\gamma)+h_{I I I}^{\max }\right) ;$

- elastic deformation zone:

$z \in\left(R_{m}+h_{x}(\gamma)+h_{I I I}^{\max } ; \infty\right)$,

where:

$R_{m}$ - radius of the tunnel;

$h_{x}(\gamma)$ and $h_{I I I}^{\max }$ - maximum height of slow developed plastic deformation zone.

As a result of dissipating and attenuation of force impact of the working body, the density will gradually change along the depth of the soil layer. The highest density can be expected in the slow deformation zone, the lowest - on the boundary of the developed plastic and elastic deformation zones in the case when soil mass will be holistic. In the case of mass destruction to a depth greater than the total height of the developed plastic and elastic deformation zones, minimum value of density will be in elastic deformation zone.

Under the impact of the roller working body on the processed soil mass, environment, depending on the values of the resulting surface deformation, shows its elastic and plastic properties. Start of working body interaction (zone I, arc $A B, \varphi_{I}$ ) (Fig. 2) is accompanied by elastic and plastic mass deformations that match the phase of compaction and displacement (seals phase and local displacements) (zone I). A further effect of the working body leads to the formation of advanced plastic flow phase (phase of significant displacements) between the formed seal core (zone II) and sealing area that is formed by the core (zone III).

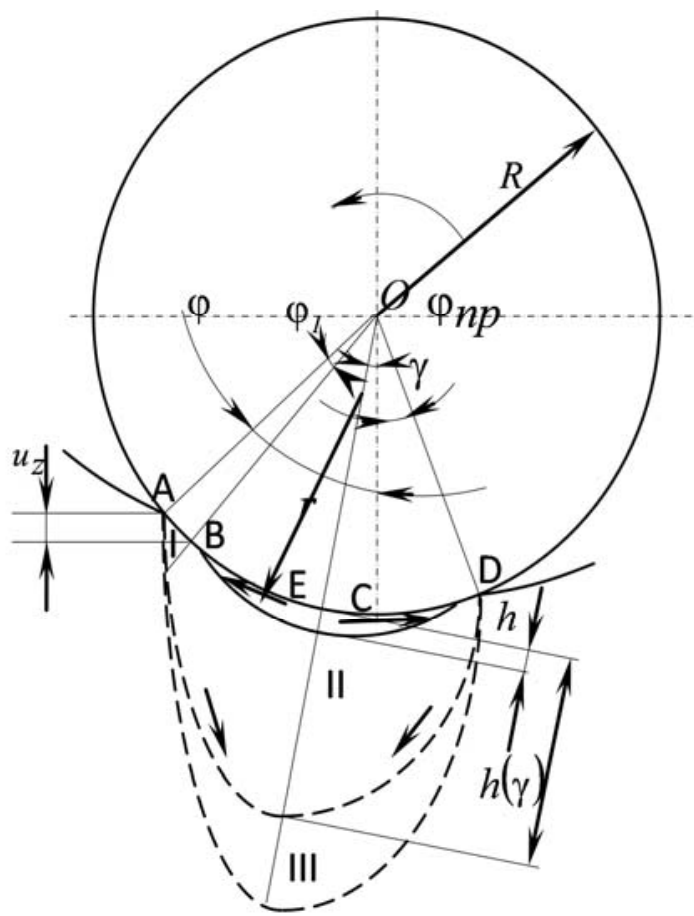

Figure 2. Scheme of rock mass processing by the roller: I - sealing zone of the working body; II - compaction core zone; III - compaction core zone of compaction 
Soil and rock mechanics focusing on the compression zones formation was studied by K. Tsymerman, Jh. Ratie, Zh. Biarez and V. Kurdyumov. The basis of this research is the hypothesis of constant orientation of the displaced platform relative to indenter surface. In addition, it allowed to determine the height change of the slow deformation zone, the maximum height occuring at point $E$, where slip surfaces overlap:

$$
h_{x}(\gamma)=R \tan \left(\frac{\pi}{4}+\frac{\varphi_{\tau}}{2}\right) \cdot(\varphi-\gamma)
$$

where:

$\varphi_{\tau}$ - angle of soil internal friction;

$R$ - working body radius;

$\varphi$ - angle of the load zone arc $A E C$;

$\gamma$ - neutral angle.

It should be noted that the planes of displacement during soil compaction are spatially located. It will lead to lateral expansion with the formation of the core additional surface, which is oriented at an angle $\frac{\pi}{4}+\frac{\varphi_{\tau}}{2}$ to the generatrix contacting surface of the working body. Compaction core shape under these conditions is shown in Figure 3.

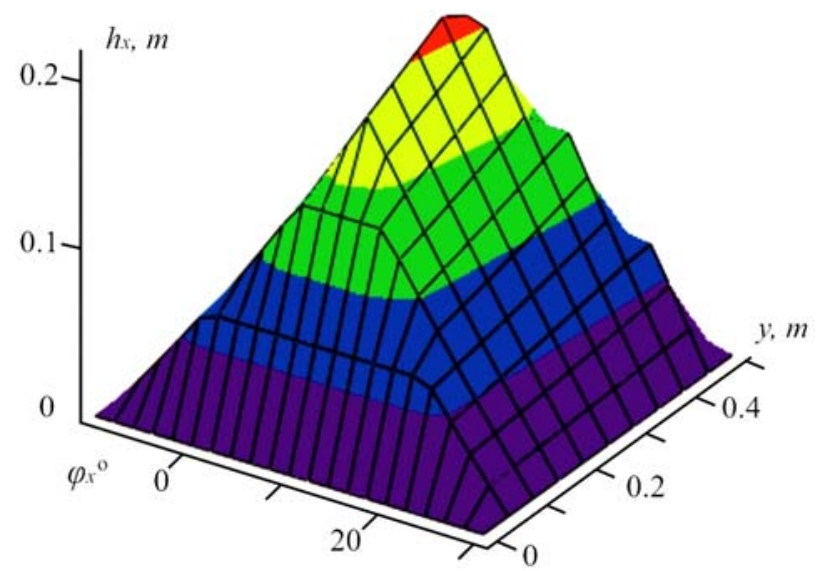

Figure 3. Shape of the compaction core $(R=0.3 \mathrm{~m}$; $L=0.5 m ; \varphi=20^{\circ}$ )

The described compaction process can take place only in the condition of the required amount of soil mixture determined by angle of capture $\varphi(\operatorname{arc} A C)$. If the amount of soil exposed to the working body impact decreases, the formed compaction core is reduced and takes the shape of a rotation body with radius $r$ and height $h$ (Johnson, 1985):

$h=\frac{R k(\cos \varphi-1)}{k-1}$;

$r=R-h$.

Distribution of compacted soil height across the contact area $\left(\varphi_{x}, y\right)$, for the case of inadequate amount of soil mixture, is shown in Figure 4.

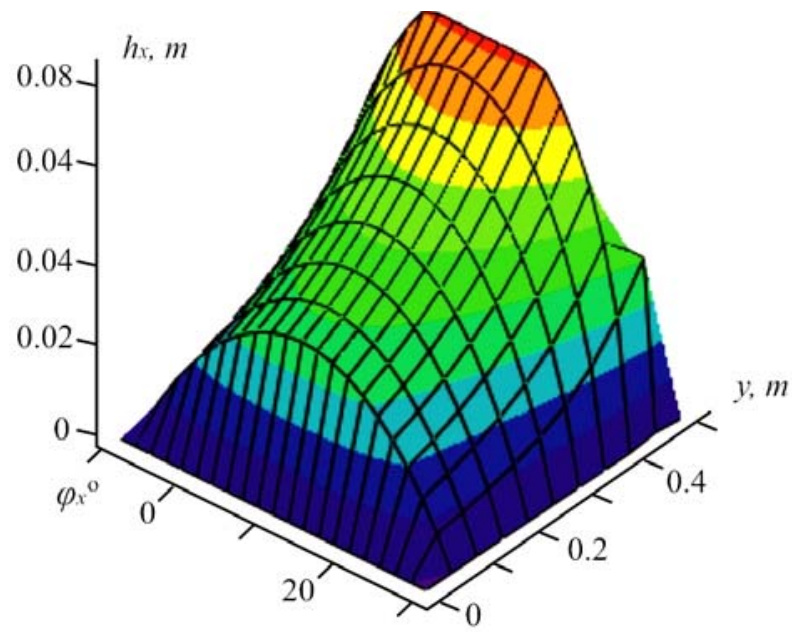

Figure 4. Compaction core form for the case of insufficient amount of soil mixture

Obtained distributions of compaction core height allow to determine the sealing contact pressures, using the equations of soil mixture volume element equilibrium, derived from T. Karman's equation (Alexander, 1972). The equations for the conditions of geotechnical properties formation of underground mine marginal layer take the following forms:

- advance zone $(\operatorname{arc} A E)$ :

$\frac{d p_{x}}{d \varphi_{x}}=p_{x} \frac{-\xi h_{x}^{\prime}-\mu R+\left(-\tan \left(\frac{\pi}{4}+\frac{\varphi_{\tau}}{2}\right)+\mu^{\prime}\right) \beta\left(R+h_{x}\right)}{\xi h_{x}} ;$

- lag zone $(\operatorname{arc} E D)$ :

$\frac{d p_{x}}{d \varphi_{x}}=p_{x} \frac{-\xi h_{x}^{\prime}-\mu R+\left(\tan \left(\frac{\pi}{4}+\frac{\varphi_{\tau}}{2}\right)-\mu^{\prime}\right) \beta\left(R+h_{x}\right)}{\xi h_{x}}$,

where $h_{x}^{\prime}=\frac{d h_{x}\left(\varphi_{x}\right)}{d \varphi_{x}}$.

Solution to differential equation of normal pressure distribution along the contact arc $\varphi_{x}$ by Euler numerical method with predictor-corrector is shown in Figure 5 as the pressure distribution surface in the contact zone for the composition of soil mixture with humidity: $W_{c}=18 \% ; \varphi_{k}=25^{\circ} ; \varphi_{n}=22^{\circ} ; \mu=0.3 ; \mu^{\prime}=0.4$; $R=0.3 ; R=0.58 \mathrm{MPa}$. The resulting distribution of normal contact pressures has convex nature which is typical for interaction of hard indenter with plastic environment, with maximum values in the zone of tangential pressures changes. The values of obtained maximum stresses $(1.6-2.21 \mathrm{MPa})$ are sufficient for compaction of soils forming adjacent contour of transportation, hydraulic and collector tunnels of cities.

To test the proposed dependences of normal and tangential pressures distributions in the models of contact interaction of compaction environments with working bodies, the calculated and experimentally determined force impacts were compared. 


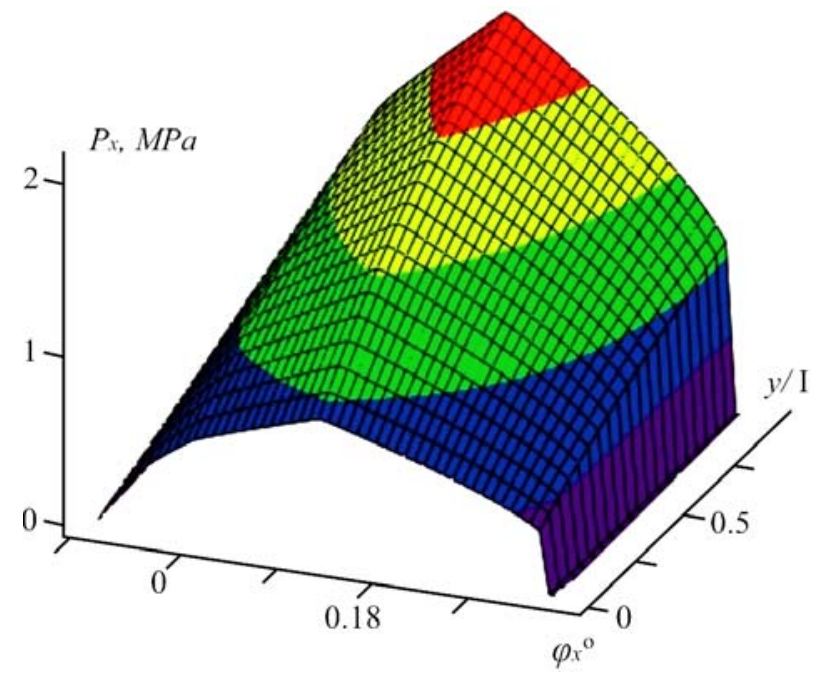

Figure 5. Distribution of normal pressures on the contact surface

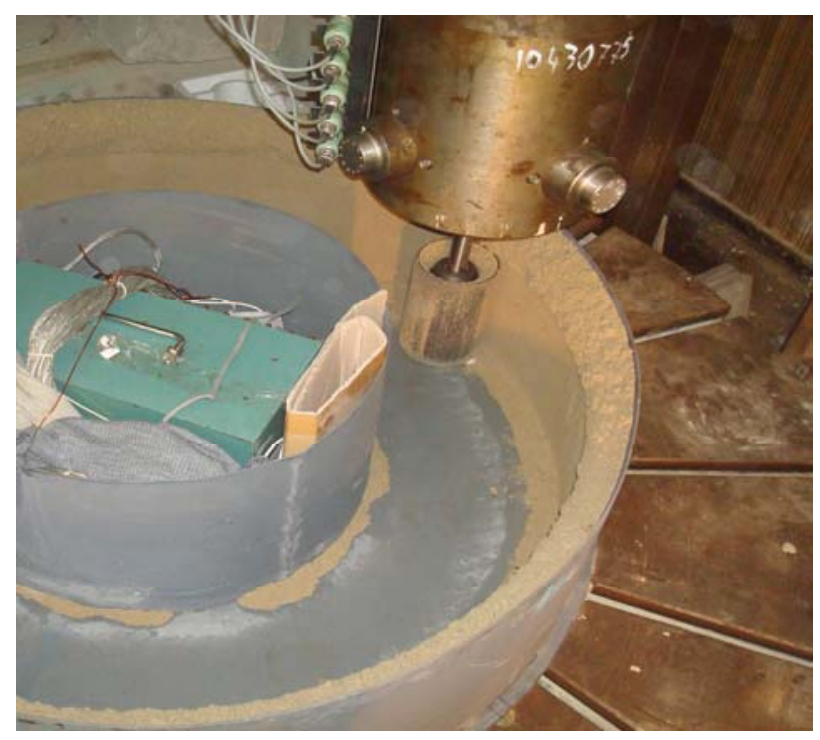

Figure 6. The formation of soil mixture by roller method
Figures 6 and 7 show the formation process and a typical graph presenting forces, arising during the impact on soil mixture which were determined by a device for measuring and recording the working body actions.

The graph shows gradual increase in measured parameters during soil mixture compaction at each pass. It confirms the importance of taking into account the distribution of strength and deformation characteristics along the contact zone. In all graphs, normal force $N$ is $1.5-$ 2 times higher than the tangent force $Q_{x}$, which corresponds to improved compacting conditions when pressing of the working body occurs due to displacement. The axial force $Q_{y}$ during roller compaction is virtually absent. The reason for the relatively low value of axial force, which equals about $4 \%$ of the normal, is formation of the lateral expansion zone at the final stage, while tangential pressures that shape the axial force are directed opposite to the direction of the working body axial movement. Thus, the resultant axial force of the lateral pressure zone balances the axial force of friction that occurs in advance and lag zones.

In measuring the force of working bodies impact on soil mixture, the data was partly obtained at the end of forming process without feeding mixture to the compaction zone. This was accompanied by the decrease in the contact zone, complete restoration of the deformable layer height and sharp reduction of force - up to $10 \%$ of the maximum value. It confirms the hypothesis about the plastic nature of deformation during roller compaction.

The components of force impact determined experimentally and on the basis of theoretically derived stress distribution diagrams for compacted soil mixture of different compositions and deformation velocities, are shown in Table 1 (component $Q_{y}$ was not theoretically determined).

Table 1. Components of force impact on the soil mixture

\begin{tabular}{|c|c|c|c|c|c|c|c|c|c|c|c|c|}
\hline \multirow{4}{*}{$\begin{array}{l}\text { Humidity of } \\
\text { mixture/clay } \\
\text { content, \% }\end{array}$} & \multicolumn{6}{|c|}{ Theoretically determined } & \multicolumn{6}{|c|}{ Experimentally obtained } \\
\hline & \multicolumn{6}{|c|}{ Velocity, $\mathrm{m} / \mathrm{s}$} & \multicolumn{6}{|c|}{ Velocity, m/s } \\
\hline & \multicolumn{3}{|c|}{0.14} & \multicolumn{3}{|c|}{5} & \multicolumn{3}{|c|}{0.14} & \multicolumn{3}{|c|}{5} \\
\hline & $N, \mathrm{kN}$ & $Q_{x}, \mathrm{kN}$ & $Q_{y}, \mathrm{kN}$ & $N, \mathrm{kN}$ & $Q_{x}, \mathrm{kN}$ & $Q_{y}, \mathrm{kN}$ & $N, \mathrm{kN}$ & $Q_{x}, \mathrm{kN}$ & $Q_{y}, \mathrm{kN}$ & $N, \mathrm{kN}$ & $Q_{x}, \mathrm{kN}$ & $Q_{y}, \mathrm{kN}$ \\
\hline $14 / 10$ & 0.19 & 0.12 & - & 0.27 & 0.17 & - & 0.17 & 0.10 & 0.02 & 0.23 & 0.15 & 0.08 \\
\hline $18 / 10$ & 0.21 & 0.13 & - & 0.32 & 0.21 & - & 0.18 & 0.12 & 0.03 & 0.28 & 0.18 & 0.09 \\
\hline $14 / 20$ & 0.25 & 0.16 & - & 0.45 & 0.29 & - & 0.22 & 0.14 & 0.06 & 0.39 & 0.26 & 0.01 \\
\hline $18 / 20$ & 0.28 & 0.18 & - & 0.60 & 0.39 & - & 0.25 & 0.15 & 0.07 & 0.54 & 0.35 & 0.02 \\
\hline $14 / 20$ & 0.31 & 0.19 & - & 0.91 & 0.59 & - & 0.27 & 0.17 & 0.09 & 0.78 & 0.52 & 0.03 \\
\hline $18 / 20$ & 0.36 & 0.23 & - & 1.12 & 0.72 & - & 0.32 & 0.20 & 0.02 & 0.96 & 0.62 & 0.06 \\
\hline
\end{tabular}

Comparison of the experimental and theoretical values of force impact components on soil mixture confirms theoretical conclusions. The difference between the results ranges from 9 to $14 \%$. 


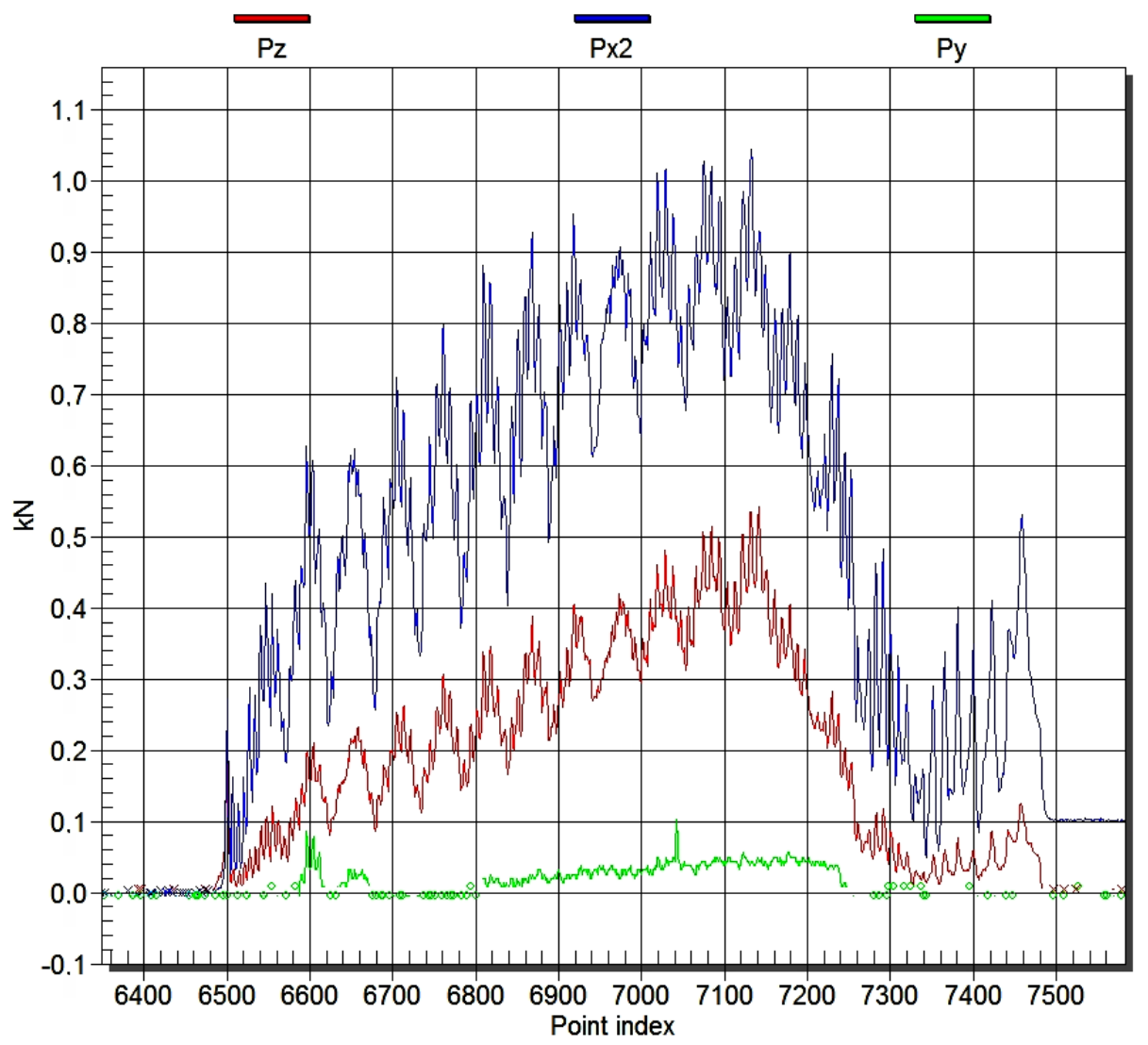

Figure 7. Changing components of force - normal $N$, tangent $Q_{x}$ and axial $Q_{y}$ during compaction of the soil layer $\left(-N ;-Q_{x} ;-Q_{y}\right)$

\section{CONCLUSION}

Comparison of experimentally determined force impact components on the processed environment with theoretically established normal and contact pressures distributions allows to confirm suitability of the proposed models for describing the contact interaction of roller working bodies with soil mixture. It also allows to use these data to develop a method for engineering calculation of principal parameters of geotechnical properties formation on the basis of the proposed approach.

\section{ACKNOWLEDGMENTS}

The authors express their gratitude to the staff of the Department of Computer Material Engineering of Superhard Composite Materials at V. Bakul Institute for Superhard Materials of the National Academy of Sciences of Ukraine for providing test instrumentation system.

\section{REFERENCES}

Alexander, J. M. (1972, February). On the theory of rolling. In Proceedings of the Royal Society of London A: Mathematical, Physical and Engineering Sciences (Vol. 326, No. 1567 , pp. 535-563). The Royal Society. http://dx.doi.org/10.1098/rspa.1972.0025

Berga, L. (2003). Roller compacted concrete dams. Lisse: A.A. Balkema.

Chiroux, R., Foster, W., Johnson, C., Shoop, S., \& Raper, R. (2005). Three-dimensional finite element analysis of soil interaction with a rigid wheel. Applied Mathematics And Computation, 162(2), 707-722.

http://dx.doi.org/10.1016/j.amc.2004.01.013
Hambleton, J., \& Drescher, A. (2008). Development of improved test rolling methods for roadway embankment construction. St. Paul, Minn.: Minnesota Department of Transportation, Research Services Section. http://dx.doi.org/10.1016/j.amc.2004.01.013

Hopkinson, I., Myatt, M., \& Tajbakhsh, A. (2004). Static and dynamic studies of phase composition in a polydisperse system. Polymer, 45(12), 4307-4314. http://dx.doi.org/10.1016/j.polymer.2004.04.006

Johnson, K. (1985). Contact mechanics. Cambridge [Cambridgeshire]: Cambridge University Press. http://dx.doi.org/10.1017/CBO9781139171731

Miura, K. (2003). Design and construction of mountain tunnels in Japan. Tunnelling And Underground Space Technology, 18(2-3), 115-126. http://dx.doi.org/10.1016/s0886-7798(03)00038-5

Ramoni, M., \& Anagnostou, G. (2010). Tunnel boring machines under squeezing conditions. Tunnelling And Underground Space Technology, 25(2), 139-157. http://dx.doi.org/10.1016/j.tust.2009.10.003

Vahedifard, F., Nili, M., \& Meehan, C. (2010). Assessing the effects of supplementary cementitious materials on the performance of low-cement roller compacted concrete pavement. Construction And Building Materials, 24(12), 2528-2535. http://dx.doi.org/10.1016/j.conbuildmat.2010.06.003

Zenunović, D., \& Folić, R. (2012). Models for behaviour analysis of monolithic wall and precast or monolithic floor slab connections. Engineering Structures, 40, 466-478. http://dx.doi.org/10.1016/j.engstruct.2012.03.007

Zinchuk, A., Mullarney, M., \& Hancock, B. (2004). Simulation of roller compaction using a laboratory scale compaction simulator. International Journal Of Pharmaceutics, 269(2), 403-415.

http://dx.doi.org/10.1016/j.ijpharm.2003.09.034 


\section{ABSTRACT (IN UKRAINIAN)}

Мета. Створення моделі процесу формування геомеханічних властивостей прилеглого контуру гірського масиву підземної виробки методом роликового пресування з урахуванням зміцнення і створення зони уповільнененої пластичної деформації.

Методика. Змодельовані основні технологічні параметри процесу обробки прилеглого контуру тунелю: розподіл нормальних тисків і висоти ядра ущільнення у залежності від основних характеристик міцності та деформаційних властивостей гірського масиву, геометрії й особливостей зони контакту роликового робочого органу з оброблюваним середовищем.

Результати. Обгрунтовано вибір розрахункової моделі процесу формування властивостей прилеглого контуру гірського масиву роликовим методом з урахуванням виникаючих процесів при деформації грунтів: виникнення пружної та пластичної деформацій, зміна характеристик грунту, виникнення ядра ущільнення. Показані основні етапи та взаємозв'язки параметрів при моделюванні процесу обробки прилеглої зони тунелю.

Наукова новизна. Наукова новизна полягає у розробці методу аналізу контактної взаємодії роликового робочого органу формуючого агрегату 3 масивом із урахуванням зміни в процесі стабілізації фізикомеханічних властивостей оброблюваного середовища, метою якого $є$ прогнозування необхідних напружень $\mathrm{i}$ глибини сформованого шару.

Практична значимість. Створено теоретичні основи формування геотехнічних властивостей прилягаючого контуру підземної виробки роликовим методом з урахуванням особливостей деформації грунтів та контактної взаємодії робочого органу з оброблюваним середовищем, які дозволяють удосконалити технологію будівництва тунелів шляхом посилення несучої здатності приконтурного масиву. Отримані результати дозволяють визначити параметри зони пружних і пластичних деформацій з метою встановлення ії висоти і виникаючої напруги.

Ключові слова: будівництво тунелів, гірський масив, трунт, роликовий робочий орган, метод

\section{ABSTRACT (IN RUSSIAN)}

Цель. Создать модель процесса формирования геотехнических свойств прилегающего контура горного массива подземной выработки методом роликового прессования с учетом упрочнения и создания зоны замедленной пластической деформации.

Методика. Смоделированы основные технологические параметры процесса обработки прилегающего контура тоннеля: распределение нормальных давлений и высоты ядра уплотнения в зависимости от основных прочностных и деформационных свойств горного массива, геометрии и особенностей зоны контакта роликового рабочего органа с обрабатываемой средой.

Результаты. Обоснован выбор расчетной модели процесса формирования свойств прилегающего контура горных массива роликовым методом с учетом возникающих процессов при деформации грунтов: возникновения упругой и пластической деформации, изменение характеристик почвы, возникновение ядра уплотнения. Показаны основные этапы и взаимосвязи параметров при моделировании процесса обработки прилегающей зоны тоннеля.

Научная новизна. Научная новизна заключается в разработке метода анализа контактного взаимодействия роликового рабочего органа формующего агрегата с массивом с учетом изменения в процессе стабилизации физико-механических свойств обрабатываемой среды, целью которого является прогнозирование необходимых напряжений и глубины сформированного слоя.

Практическая значимость. Созданы теоретические основы формирования геотехнических свойств прилегающего контура подземной выработки роликовым методом с учетом особенностей деформации грунтов и контактного взаимодействия рабочего органа с обрабатываемой средой, которые позволяют усовершенствовать технологию строительства тоннелей путем усиления несущей способности приконтурного массива. Полученные результаты позволяют определить параметры зоны упругих и пластических деформаций с целью установления ее высоты и возникающих напряжений.

Ключевые слова: строчтельство тоннелей, горный массив, почва, роликовый рабочий орган, метод

\section{ARTICLE INFO}

Received: 23 October 2015

Accepted: 15 December 2015

Available online: 30 March 2016

\section{ABOUT AUTHORS}

Viktor Kravets, Doctor of Technical Sciences, Professor of the Department of Geobuilding and Mining Technologies, National Technical University of Ukraine "Kyiv Polytechnic Institute", 37 Peremogy Ave., 30056, Kyiv, Ukraine. E-mail: kravets@geobud.kiev.ua

Stefan Zaychenko, Doctor of Technical Sciences, Professor of the Department of Electromechanics Equipment Productions, National Technical University of Ukraine "Kyiv Polytechnic Institute", 37 Peremogy Ave., 30056, Kyiv, Ukraine. E-mail: zstefv@gmail.com

Gennadiy Gayko, Doctor of Technical Sciences, Professor of the Department of Geobuilding and Mining Technologies, National Technical University of Ukraine "Kyiv Polytechnic Institute", 37 Peremogy Ave., 30056, Kyiv, Ukraine. E-mail: gayko.kpi@meta.ua 